\title{
Estrogen Regulates the Development of Brain-Derived Neurotrophic Factor mRNA and Protein in the Rat Hippocampus
}

\author{
Derek T. Solum ${ }^{1,2}$ and Robert J. Handa ${ }^{1}$ \\ ${ }^{1}$ Department of Anatomy and Neurobiology, Colorado State University, Fort Collins, Colorado 80523, and ${ }^{2}$ Department of \\ Cell Biology, Neurobiology, and Anatomy, Loyola University Chicago, Maywood, Illinois 60153
}

\begin{abstract}
During development, estrogen has a variety of effects on morphological and electrophysiological properties of hippocampal neurons. Brain-derived neurotrophic factor (BDNF) also plays an important role in the survival and differentiation of neurons during development. We examined the effects of gonadectomy with and without estrogen replacement on the mRNA and protein of BDNF and its receptor, trkB, during early postnatal development of the rat hippocampus. We used immunocytochemistry to demonstrate that estrogen receptor $\alpha(E R \alpha)$ and BDNF were localized to the same cells within the developing hippocampus. BDNF and $\mathrm{ER} \alpha$ were colocalized in pyramidal cells of the CA3 subregion and to a lesser extent in CA1. To determine whether BDNF mRNA was regulated by estrogen during development, we gonadectomized male rat pups at postnatal day 0 (P0) and examined mRNA and protein levels
\end{abstract}

from $\mathrm{P} 0$ to $\mathrm{P} 25$ using real-time reverse transcription-PCR and Western blot analysis. After gonadectomy, BDNF mRNA levels are significantly reduced on $\mathrm{P} 7$, but after treatment of gonadectomized animals with estradiol benzoate on P0, levels at all ages were similar to those in intact animals. BDNF mRNA changes after gonadectomy are accompanied by an increase in the levels of BDNF protein, which were reduced by estrogen treatment at $\mathrm{P} 0$. We also examined the effect of postnatal estrogen treatment on trkB. There were no significant changes in trkB mRNA or protein in gonadectomized or estrogenreplaced animals. These results suggest that a direct interaction may exist between $\mathrm{ER} \alpha$ and BDNF to alter hippocampal physiology during development in the rat.

Key words: estrogen; estrogen receptor; $E R \alpha ; B D N F ;$ trkB; hippocampus; development
It is well established that estrogen is involved in the differentiation and plasticity of hippocampal neurons. For instance, estrogens influence general neurobiological functions such as perceptual-spatial skills and learning and memory (McEwen, 1983; Smith, 1994; Luine, 1997). Estrogens may also act to alter certain specific pathologies such as epileptic seizure threshold (Terasawa and Timiras, 1968; Buterbaugh and Hudson, 1991) and perhaps Alzheimer's disease (Henderson et al., 1996) and Parkinson's disease (Leranth et al., 2000). The sites of action for the effects of estradiol on cognitive performance and pathology have not been established, but one probable site is the hippocampus, a sexually dimorphic, steroid-responsive brain region (Juraska et al., 1989; Roof and Havens, 1992; Woolley and McEwen, 1992).

In the adult rat, it has been demonstrated that hippocampal pyramidal neurons express mRNA for both isoforms ( $\alpha$ and $\beta$ ) of the estrogen receptor (Shughrue et al., 1997). Moreover, ovarian steroids act during a perinatal sensitive period to alter the patterns of neuronal cell death and synaptic connectivity (McEwen, 1983). Additionally, we have demonstrated that estrogen receptor $\alpha(\mathrm{ER} \alpha)$ is transiently expressed in developing hippocampal pyramidal neurons (Solum and Handa, 2001). Their biological roles in such processes, however, remain uncertain.

Brain-derived neurotrophic factor (BDNF) is emerging as an

Received July 13, 2001; revised Dec. 18, 2001; accepted Dec. 21, 2001.

This work was supported by National Science Foundation Grant 96-04723 (R.J.H.), National Institutes of Health Grants NS39951 and AA12693 (R.J.H.), and United States Public Health Service National Research Service Award Predoctoral Fellowship F31 MH12292 (D.T.S.).

Correspondence should be addressed to Robert J. Handa, Department of Anatomy and Neurobiology, Colorado State University, Fort Collins, CO 80526. E-mail: robert.handa@colostate.edu.

Copyright (C) 2002 Society for Neuroscience $\quad 0270-6474 / 02 / 222650-10 \$ 15.00 / 0$ important mediator of activity-dependent modifications in synaptic strength (Lohof et al., 1993; Levine et al., 1995) and plays important roles in the survival and growth of neurons (Barde, 1989; Davies, 1994). For instance, BDNF regulates dendritic and axonal growth (Cohen-Cory and Fraser, 1995; McAllister et al., 1995) and the efficacy of synaptic transmission at excitatory synapses on hippocampal neurons (Vicario-Abejon et al., 1998; Sherwood and Lo, 1999).

Interestingly, neurons in the adult rat forebrain of both sexes coexpress estrogen and neurotrophin receptors and are the sites of estrogen and neurotrophin synthesis (Toran-Allerand et al., 1992; Miranda et al., 1994). Consistent with this, the relative levels of BDNF mRNA within specific regions of the hippocampus fluctuate significantly over the course of the estrous cycle (Gibbs, 1998), and increased levels of BDNF mRNA after longterm estrogen treatment have been reported in this brain region (Singh et al., 1995). It has also been shown that estrogen and neurotrophin receptor coexpression leads to convergence of their signaling pathways (Toran-Allerand et al., 1999). However, whether estrogen influences BDNF or trkB expression in the developing hippocampus in vivo and whether the developmental actions of estrogen on neurons are mediated directly or indirectly via interactions with growth factors and their signaling pathways are unclear.

Given the increasing evidence for effects of BDNF on neuronal connectivity and activity-dependent synaptic plasticity in the adult brain, we hypothesized that estrogen could similarly effect BDNF expression during development. This may subsequently contribute to the organizational effects of estrogen on brain structure and function. In this study, we examined the effect of gonadectomy and estrogen treatment on the developmental ex- 
pression of mRNAs and protein for BDNF and its receptor, trkB, using immunocytochemistry, real-time quantitative reverse transcription (RT)-PCR, and Western blot analysis.

\section{MATERIALS AND METHODS}

Animals. Neonatal male and female rats of various ages from timed pregnant Sprague Dawley females and adult male and female adult rats were obtained from Charles River Laboratories (Portage, MI). Animals were housed under a $12 \mathrm{hr}$ light/dark cycle (lights on at 7 A.M.) with food and water available ad libitum. On parturition, litters were sexed and thinned to eight pups (four males and four females). Shortly after birth (4-6 hr), some pups were gonadectomized under hypothermia anesthesia. Of these, half received a single subcutaneous injection of $10 \mu \mathrm{g}$ of estradiol benzoate in $50 \mu \mathrm{l}$ of sesame oil, whereas the other half received oil alone. This protocol has been shown to result in a decrease in plasma testosterone levels, an increase in estrogen receptor levels, and the abolishment of male sexual behavior (Ulibarri et al., 1990; Kuhnemann et al., 1995; McCormick et al., 1998; Atanassova et al., 1999), presumably by overcoming the sequestering ability of circulating $\alpha$-fetoprotein. Animals were subsequently killed at postnatal day 4 (P4), P7, P10, P15, P20, and P25 (day of birth was P0). Adult males and females were killed at 3-4 months of age. An additional group of intact animals were killed on P0. All animal protocols were previously approved by the Animal Care and Use Committee at Colorado State University.

Hippocampal cultures. Neuronal cultures were prepared from rat embryonic hippocampus at embryonic day 18 (E18). Embryos were recovered after maternal cesarean delivery under halothane anesthetic, and the hippocampi were dissected from the brain and minced. Individual cells were isolated by trituration in HBSS (Invitrogen, Rockville, MD) without $\mathrm{Ca}^{2+}$ and $\mathrm{Mg}^{2+}$. After allowing nondispersed tissues to settle for $3 \mathrm{~min}$, the supernatant was transferred to a sterile $15 \mathrm{ml}$ tube and centrifuged for $1 \mathrm{~min}$ at $200 \times \mathrm{g}$. The pellet was gently resuspended in charcoal-stripped media without phenol red, and an aliquot was added to trypan blue stain for a hemocytometer count. Cells were then plated on poly-D-lysine $(0.05 \mathrm{mg} / \mathrm{ml}$; Sigma, St. Louis, MO)-coated coverslips at a density of 50,000 cells $/ \mathrm{cm}^{2}$ and incubated at $37^{\circ} \mathrm{C}$ in $5 \% \mathrm{CO}_{2}$ atmosphere. After $4 \mathrm{~d}$ in culture, half of the media was replaced, and the cultures were treated with estradiol benzoate $(0.01,0.1,1.0,10$, and 100 $\mathrm{nM}$ ) or vehicle for $24 \mathrm{hr}$ before processing.

Antibodies. Anti-ER $\alpha$ antibodies, raised against the 14 most $\mathrm{C}$-terminal amino acids, were purchased from Upstate Biotechnologies (Lake Placid, NY; C1355); anti-ER $\beta$ antibodies were from Zymed Laboratories (San Francisco, CA) and were raised against amino acids 468-485 of the ER $\beta$ protein (Z8P); GABA (A2052) antiserum was obtained from Sigma; BDNF (sc-546) and trkB (sc-12) antiserum were from Santa Cruz Biotechnology (Santa Cruz, CA) and map to the N-and $\mathrm{C}$-terminal regions, respectively. To ensure immunoreactive specificity, competition experiments were performed using the immunoreactive peptides for BDNF (sc-546P) and trkB (sc-12P).

Double-label immunocytochemistry. Neonatal rat pups were anesthetized with halothane and killed by perfusion with $10-30 \mathrm{ml}$ of $0.1 \mathrm{M}$ ice-cold PBS followed by $10-30 \mathrm{ml}$ of freshly prepared ice-cold $4 \%$ paraformaldehyde in $0.1 \mathrm{M}$ PBS. Adult animals were anesthetized and killed similarly but were perfused with $\sim 200 \mathrm{ml}$ of $0.1 \mathrm{M}$ PBS followed by $200 \mathrm{ml}$ of freshly prepared $4 \%$ paraformaldehyde in $0.1 \mathrm{M}$ PBS. Brains were removed and placed into $30 \%$ sucrose in $0.1 \mathrm{M}$ PBS at $4^{\circ} \mathrm{C}$ until permeated. Next, the brains were sectioned $30 \mu \mathrm{m}$ thick on a cryostat and placed into $0.1 \mathrm{~m}$ PBS containing $0.1 \%$ sodium azide. The tissue was processed for immunocytochemistry as described previously (Kerr et al., 1995). Briefly, tissue from three P10 males was incubated with $0.3 \%$ $\mathrm{H}_{2} \mathrm{O}_{2}$ in 0.1 M PBS to quench any nonspecific reaction with endogenous peroxidases. Subsequently, nonspecific antibody binding was blocked by incubation with $4 \%$ normal goat serum (NGS) in $0.1 \mathrm{M}$ PBS. Tissue was then incubated for $48 \mathrm{hr}$ at $4^{\circ} \mathrm{C}$ with $\operatorname{ER} \alpha(1: 10,000)$ or $\operatorname{ER} \beta(1: 1500)$ antiserum in the presence of $2 \%$ NGS and $0.1 \%$ Triton X-100 (TX). The tissue was then washed and incubated for $2 \mathrm{hr}$ with biotinylated goat anti-rabbit IgG (1:500; Vector Laboratories, Burlingame, CA) followed by standard washes and incubation with an avidin-biotin-horseradish peroxidase complex (1:500; Vector Laboratories) for $1 \mathrm{hr}$. Standard washes were done three times at room temperature in $0.1 \mathrm{M}$ PBS with $0.1 \%$ TX. Finally, staining was visualized with a Tris-buffered saline solution containing nickel-intensified diaminobenzidine (DAB, $0.5 \mathrm{mg} /$ $\mathrm{ml}$; Sigma) and hydrogen peroxide $(0.01 \%)$ for $6-10 \mathrm{~min}$. Nickelintensified DAB was prepared by adding $0.3 \mathrm{mg} / \mathrm{ml}$ of nickel ammonium sulfate to the DAB solution, resulting in a dark blue stain.
Next, the tissue was washed and processed for BDNF immunoreactivity using BDNF antiserum (1:500). Essentially, the tissue was processed as above, except that after incubating with $0.3 \% \mathrm{H}_{2} \mathrm{O}_{2}$, the tissue was blocked for $2 \mathrm{hr}$ in 6\% NGS. Tissue was then washed (three times for 15 min in $0.1 \mathrm{M}$ PBS-TX) before the secondary antibody incubation as described above. After a final washing step, this reaction was developed with normal DAB $\left(0.5 \mathrm{mg} / \mathrm{ml}\right.$ and $\left.0.01 \% \mathrm{H}_{2} \mathrm{O}_{2}\right)$ to produce a brown reaction product. After developing, the tissue was rinsed and mounted on glass slides. The mounted sections were air-dried overnight at room temperature, and the slides were processed through a series of increasing alcohols, cleared with xylene, and coverslipped with Permount (Fisher Scientific, Pittsburgh, PA). Double-labeled cells were visualized by light microscopy as cells containing a dark blue nucleus $(\operatorname{ER} \alpha)$ and a brown cytoplasm (BDNF).

Fluorescent double-label immunocytochemistry on dissociated hippocampal cells was essentially similar to that described above with some exceptions. After $5 \mathrm{~d}$ in vitro, culture media was removed, and the cells were fixed with $10 \%$ buffered formalin for $10 \mathrm{~min}$, after which the cells were washed three times in PBS-TX. After blocking and primary antibody incubations similar to those described above, the cells were washed and incubated for $2 \mathrm{hr}$ with Alexa Fluor 594 goat anti-rabbit IgG conjugate (1:2000; Molecular Probes, Eugene, OR). Cells were then washed and incubated with unlabeled goat anti-rabbit IgG (6\% in PBSTX) for $1 \mathrm{hr}$ to block remaining binding sites on ER antibodies. The cells were then processed for the second primary antibody as described above with similar blocking, primary, and secondary antibody incubations. After another washing step, cells were incubated for $1 \mathrm{hr}$ with Alexa Fluor 488 streptavidin conjugate (1:1500; Molecular Probes). After a final washing step, the coverslips were affixed to Superfrost Plus slides with Vectashield mounting medium (Vector Laboratories). Cells were analyzed with a Zeiss (Thornwood, NY) Axioplan 2 imaging microscope, and images were captured with a Zeiss AxioCam digital camera.

Total RNA isolation and reverse transcription. Neonatal rat pups were decapitated; the brains were quickly removed; and the medial basal hypothalamus and hippocampal regions CA1 and CA3 were dissected. Total RNA was isolated similarly to the protocol of Chomczynski and Sacchi (1987). Briefly, brain tissue was homogenized in $250 \mu \mathrm{l}$ of buffer containing $4 \mathrm{~m}$ guanidinium isothiocyanate, $25 \mathrm{~mm}$ Na citrate, $\mathrm{pH} 7.0$, $0.5 \%$ sarcosyl, and $0.1 \mathrm{~m} \beta$-mercaptoethanol on ice. Subsequently, $25 \mu \mathrm{l}$ of $2 \mathrm{~m} \mathrm{NaOAc}, \mathrm{pH} 4.0,250 \mu \mathrm{l}$ of buffer-saturated phenol, $\mathrm{pH} 4.3$, and 50 $\mu \mathrm{l}$ of chloroform/isoamyl alcohol (49:1) were added, and the mixture was vortexed. The samples were then centrifuged at $14,000 \times g$ for $20 \mathrm{~min}$ at $4^{\circ} \mathrm{C}$. The aqueous phase was recovered, and the RNA was ethanolprecipitated. The resulting RNA was washed with ice-cold $70 \%$ ethanol and reconstituted in $50 \mu \mathrm{l}$ of RNase-free water. The RNA content was measured with a spectrophotometer, and only those samples with a 260:280 ratio of $>1.6$ were used.

Two micrograms of total RNA were reverse-transcribed with Superscript II reverse transcriptase (Invitrogen) using oligo-dT primers, dNTPs (100 mM each), first-strand buffer (in mM: 100 Tris-Cl, $900 \mathrm{KCl}$, and $1 \mathrm{MgCl}_{2}$ ), and $2.5 \mathrm{~mm}$ dithiothreitol. The reaction was performed at room temperature for $10 \mathrm{~min}$ followed by $50 \mathrm{~min}$ at $42^{\circ} \mathrm{C}$. The reverse transcriptase was then denatured at $95^{\circ} \mathrm{C}$ for $10 \mathrm{~min}$ and stored at $-80^{\circ} \mathrm{C}$ until used.

Real-time quantitative PCR. Real-time quantitative PCR was performed using the LightCycler system (Roche Molecular Biochemicals, Indianapolis, IN). In this system, PCR occurs in borosilicate glass capillaries, which have a high surface-to-volume ratio to ensure rapid equilibration between the air and the reaction components. A highly specific double-stranded (ds)DNA-binding dye, SYBR green I (Molecular Probes), which only fluoresces when bound to dsDNA, is used to determine the concentration of amplified products. SYBR green I binds to the minor groove of dsDNA, and fluorescence is greatly enhanced by binding. During the various stages of PCR, different intensities of fluorescence signals can be detected, depending on the amount of dsDNA that is present. The $530 \mathrm{~nm}$ fluorescence is recorded at the end of the elongation phase, and increasing amounts of PCR product are monitored from cycle to cycle. By comparing the amount of unknown cDNA with a curve of amounts of a given cDNA amplified concurrently, real-time PCR eliminates the need for competitive in-tube standards with identical primer sets as targets (Morrison et al., 1998).

To prevent nonspecific amplification, we used hot-start PCR with dNTPs, specific primers, PCR buffer (100 mM Tris-Cl, $1.5 \mathrm{~mm} \mathrm{MgCl}_{2}, 0.5$ $\mathrm{U}$ of Taq polymerase, $0.5 \mathrm{U}$ of Taq antibody (Invitrogen), and $2 \mu \mathrm{l}$ of $10 \times$ stock SYBR green I). Specific primers were as follows: BDNF 
(GenBank accession number M61178), forward primer position 245 and reverse primer position 711; and trkB (GenBank accession number M55291), forward primer 2091 and reverse primer 2406. Primers were developed using Oligo software (version 6.51; Molecular Biology Insights, Cascade, CO). All samples were amplified at 40 cycles, which is $\sim 5-10$ cycles beyond the beginning of the linear phase of amplification. Specifically, an initial melting step was done at $95^{\circ} \mathrm{C}$ for 2 min followed by 40 cycles of a $95^{\circ} \mathrm{C}$ melting step for $1 \mathrm{sec}$, an annealing step $\left(60^{\circ} \mathrm{C}\right.$ for trkB and $64^{\circ} \mathrm{C}$ for $\left.\mathrm{BDNF}\right)$ for $5 \mathrm{sec}$, and a $72^{\circ} \mathrm{C}$ elongation step $(13 \mathrm{sec}$ for trkB and $18 \mathrm{sec}$ for BDNF). In all experiments, samples containing no template were included to serve as negative controls. To ensure that the standard and unknown samples amplified equivalently, additional control experiments were conducted in which a known amount of BDNF or trkB cDNA (from the standard curve) was added to the unknown samples. These results were then compared with the sum of those obtained from the known and unknown samples amplified independently and were not significantly different $(p=0.797)$.

Construction of the BDNF and TrkB standard curve. To determine the absolute concentration of the target transcript, conventional PCR for BDNF and TrkB was used to generate a cDNA. The amplified cDNA was purified using the Qiagen (Valencia, CA) PCR purification kit according to the manufacturer's directions. The purified PCR products were serially diluted at a range of $30 \mathrm{ng}$ to $30 \mathrm{fg}$ and this curve was run in duplicate alongside the unknown samples.

$m R N A$ quantitative analysis. After real-time PCR, the absolute concentration of mRNA in each sample was determined by analysis with LightCycler data analysis software. This software plots a standard curve of the crossing line intercepts of the standards versus the known concentrations of these standards. The crossing line intercept is parallel to the $x$-axis on a graph of fluorescence intensity versus cycle number and occurs at the point where template amplification enters the logarithmic phase of the curve. Samples with a higher concentration of starting material enter the logarithmic phase earlier than samples with a lower concentration of starting material and therefore have a smaller crossing point value. The crossing line intercept of an unknown sample is subsequently compared with the standard curve to generate a quantitative amount of starting material. In each case, the point at which the crossing line intercepts the log-linear region of each curve is used to generate the concentration of that sample.

Western blot analysis. Animals were killed at the ages described above, and the brains were quickly removed. The hippocampi were dissected and individually homogenized in $200 \mu \mathrm{l}$ of $50 \mathrm{~mm}$ Tris buffer, $\mathrm{pH} 7.2$, $4^{\circ} \mathrm{C}$, containing $1 \mathrm{~mm}$ EDTA, $1 \mathrm{~mm}$ phenylmethylsulfonyl fluoride, $1 \mathrm{~mm}$ leupeptin, $1 \mu \mathrm{g} / \mathrm{ml}$ antipain, and $1 \mu \mathrm{g} / \mathrm{ml}$ aprotinin. Protein concentrations were determined using the BCA protein assay (Pierce, Rockford, IL). Homogenates were mixed 1:1 with sample buffer containing $10 \%$ glycerol, $2 \%$ SDS, $5 \% \beta$-mercaptoethanol, and $0.05 \%$ bromophenol blue and boiled for $5 \mathrm{~min}$. For each age, $20 \mu \mathrm{g}$ of protein was loaded into each well. The samples were separated on $8 \%(\operatorname{trkB})$ or $12 \%$ (BDNF) SDSpolyacrylamide gels along with biotinylated molecular weight standards (Bio-Rad, Hercules, CA). After electrophoresis, the proteins were electrically transferred to nitrocellulose in $49.6 \mathrm{~mm}$ Tris, $384 \mathrm{~mm}$ glycine, and $0.01 \%$ SDS at $30 \mathrm{~V}$ overnight followed by $80 \mathrm{~V}$ for $1 \mathrm{hr}$. The gels then were stained with Coomassie blue to confirm equal loading per lane. After transfer, blots were incubated in Tris-buffered saline with $0.1 \%$ Tween 20 (TBST) containing 5\% nonfat milk, 2\% bovine serum albumin, and $0.1 \%$ sodium azide. Subsequently, blots were incubated with either BDNF or trkB (1:500) antiserum for $48 \mathrm{hr}$ at $4^{\circ} \mathrm{C}$ in TBST containing $2 \%$ nonfat milk and $0.1 \%$ sodium azide. Blots were also processed without primary antibodies or antibodies that had been preabsorbed with the immunoreactive peptide to serve as controls. After primary antibody incubation, the blots were washed (three times, $15 \mathrm{~min}$ each in TBST at $25^{\circ} \mathrm{C}$ ) and incubated with horseradish peroxidaseconjugated goat anti-rabbit antibodies $(1 \mu \mathrm{g} / \mathrm{ml}$, Vector Laboratories, Burlingame, CA). Immunoreactive bands were visualized with an enhanced chemiluminescence system (Amersham Biosciences, Arlington Heights, IL) according to the manufacturer's directions. To ensure that each lane was loaded with an equivalent amount of protein, the blots were stripped with $0.2 \mathrm{M} \mathrm{NaOH}$ and reprobed with anti-actin serum (1:10,000; Chemicon, Temecula, CA) as described above. After immunoblotting, digitized images of immunoreactive bands for target (BDNF and trkB) and control (actin) products were imported into NIH Image software (version 1.62), and the average OD of each band was measured (based on a gray scale of 0-256 arbitrary units, 0 being white and 256 being black). Additional background measurements were taken from each film and subtracted from these values. A ratio of BDNF and trkB to actin was then determined, and these values were compared across development for statistical significance.

Statistical analyses. All analyses were performed using multiway ANOVA (StatView; SAS Institute Inc, Cary, NC). Significant values were subsequently verified with the Tukey-Kramer post hoc analysis.

\section{RESULTS}

Estrogen receptor $\alpha$, but not $\beta$, colocalizes with BDNF in hippocampal pyramidal cells in vivo and in vitro

In our initial studies, we sought to determine whether estrogen receptors $\alpha$ and $\beta$ were colocalized with BDNF in neurons of the developing rat hippocampus using double-label immunocytochemistry. We demonstrated that $\mathrm{ER} \alpha$ and BDNF were highly colocalized in pyramidal cells of the CA1 and CA3 hippocampal subregions of the intact male and female rat on postnatal day 10 (Fig. 1). We chose this age on the basis of our previous experiments showing that although little or no $\mathrm{ER} \alpha$-positive cells are observed on postnatal day 0, a transient increase in ER $\alpha$ occurs from postnatal days 4 to 10 (Solum and Handa, 2001). Our results, presented here, demonstrate that $\mathrm{ER} \alpha$ and $\mathrm{BDNF}$ were colocalized in stratum pyramidale of the CA3 subregion and to a lesser extent in the CA1 subregion. Double-labeled neurons are visualized as cells with a dark blue nucleus and a brown cytoplasm. Additionally, a few scattered $\mathrm{ER} \alpha$-immunoreactive neurons were also observed in stratum radiatum and oriens. However, these cells did not express BDNF as well and are likely nonpyramidal interneurons.

Next we examined whether ER $\beta$ was also colocalized with BDNF in the developing rat hippocampus. Although we observed a few neurons in which $\operatorname{ER} \beta$ and BDNF were colocalized in the neonatal hippocampus, most BDNF-immunoreactive cells were ER $\beta$-negative (Fig. 1). In all of the samples we examined, the intensity level of $\operatorname{ER} \beta$ immunoreactivity was much less than that for $\mathrm{ER} \alpha$. Additionally, in each of these experiments, we did not observe an obvious sex difference in the number or intensity of immunoreactivity for $\mathrm{ER}(\alpha$ and $\beta$ ) or BDNF.

It is difficult, however, to determine the extent to which cells are double-labeled because of the fact that BDNF-expressing pyramidal cells are densely packed in stratum pyramidale of the hippocampus. Because of this, we examined whether BDNF and ERs are colocalized in primary hippocampal cells grown at moderate density in vitro for $5 \mathrm{~d}$. Additionally, we double labeled primary hippocampal cultures with $\mathrm{ER} \alpha$ and GABA to confirm our previous findings in vivo showing that $\operatorname{ER} \alpha$ is primarily located in pyramidal cells, not interneurons. These experiments confirmed our findings in vivo and demonstrated that $\operatorname{ER} \alpha$, but not $\operatorname{ER} \beta$, was colocalized with BDNF in hippocampal pyramidal cells grown in vitro (Fig. 2). In this experiment, most immunopositive cells were $\mathrm{ER} \alpha^{+} / \mathrm{BDNF}^{+}$, although some $\mathrm{ER} \alpha^{-} / \mathrm{BDNF}^{+}$ cells were also present. We did not observe any $\mathrm{ER} \alpha^{+} / \mathrm{BDNF}^{-}$, $\mathrm{ER} \beta^{+} / \mathrm{BDNF}^{+}$, or $\mathrm{ER} \alpha^{+} / \mathrm{GABA}^{+}$cells.

\section{BDNF mRNA levels are decreased in the hippocampus after neonatal gonadectomy, and this effect can be reversed by a single injection of estrogen}

Using quantitative real-time RT-PCR, we examined the expression of BDNF mRNA in the CA1 and CA3 hippocampal subregions of the intact male rat during development and compared these values with those from males that had been castrated on postnatal day 0 and immediately given a single injection of oil vehicle or estradiol benzoate (Fig. 3). Because injected estrogen levels have a longer half-life in newborn rats than in older animals 

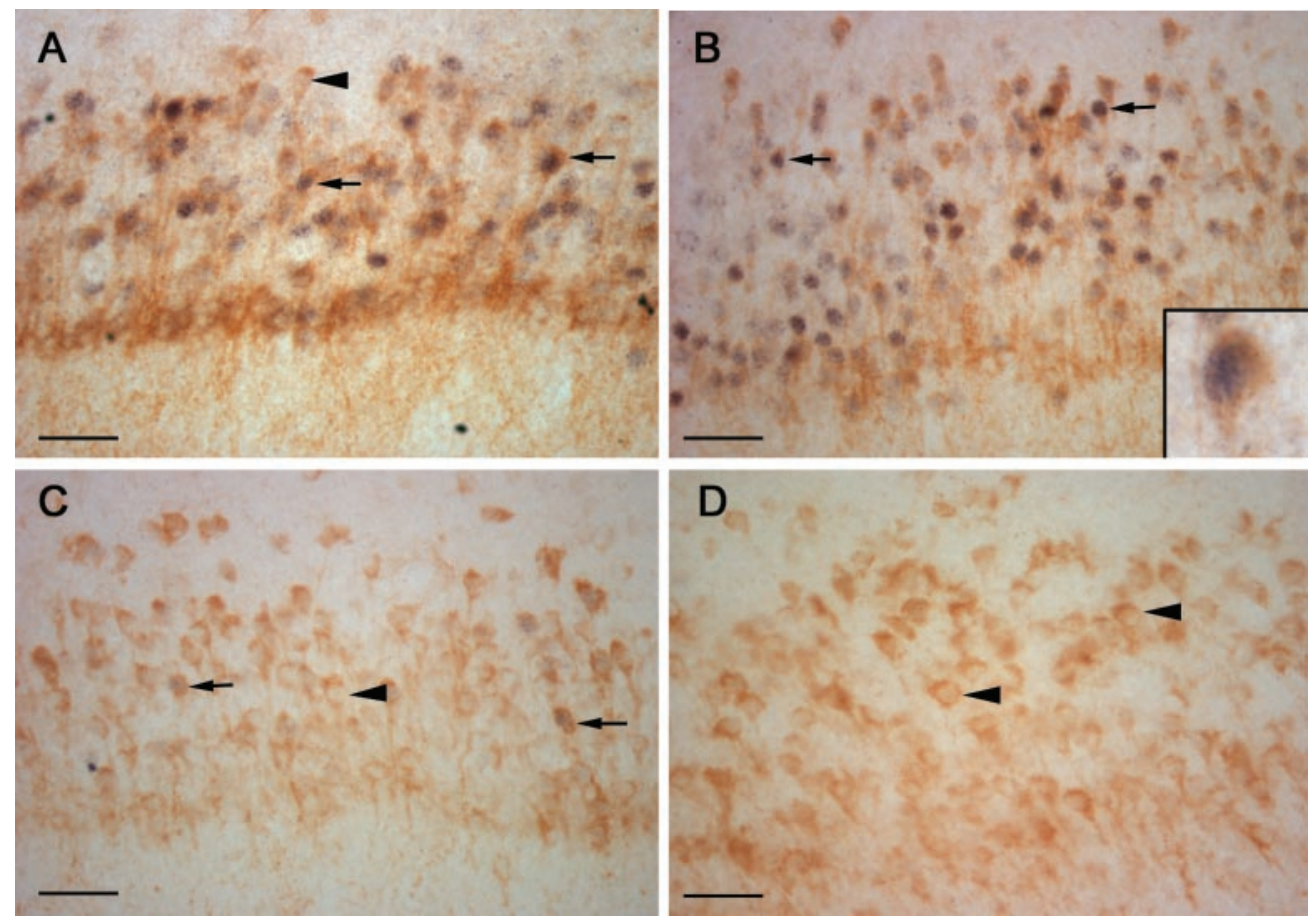

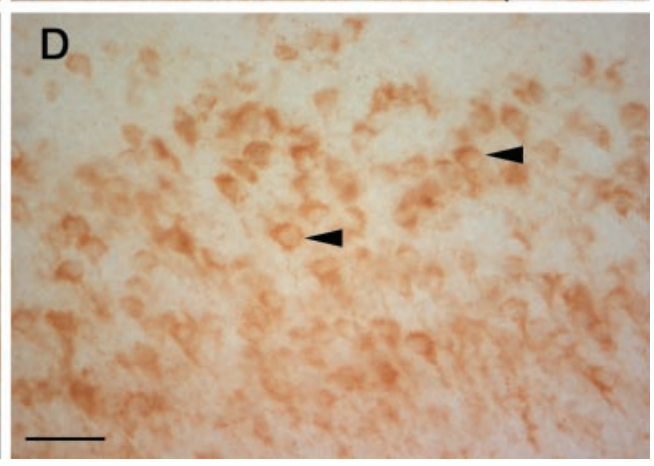

Figure 1. Double-label immunocytochemistry of estrogen receptor ( $\alpha$ and $\beta)$ and BDNF in the neonatal hippocampus. Double-label immunocytochemistry in the P10 male hippocampus was used to colocalize $\mathrm{ER} \alpha$ and $\mathrm{BDNF}$ to pyramidal neurons in the CA1 $(A)$ and CA3 $(B)$ hippocampal subregions. $\mathrm{ER} \alpha$ immunoreactivity is visualized as a blue nuclear stain, whereas BDNF immunoreactivity is visualized as a brown cytoplasmic stain. Most immunopositive cells were $\mathrm{ER} \alpha^{+} / \mathrm{BDNF}^{+}$ (arrows, inset), although some $\mathrm{ER} \alpha^{-}$ $\mathrm{BDNF}^{+}$cells (arrowheads) were also observed. ER $\beta$ and BDNF were not appreciably colocalized in either the CA1 $(C)$ or CA3 $(D)$ hippocampal subregions of the intact P10 male rat. A few $\mathrm{ER} \beta^{+} / \mathrm{BDNF}^{+}$cells (arrows) were observed, but most were $\mathrm{ER} \beta^{-} / \mathrm{BDNF}^{+}$ (arrowheads). Scale bar, $50 \mu \mathrm{m}$.
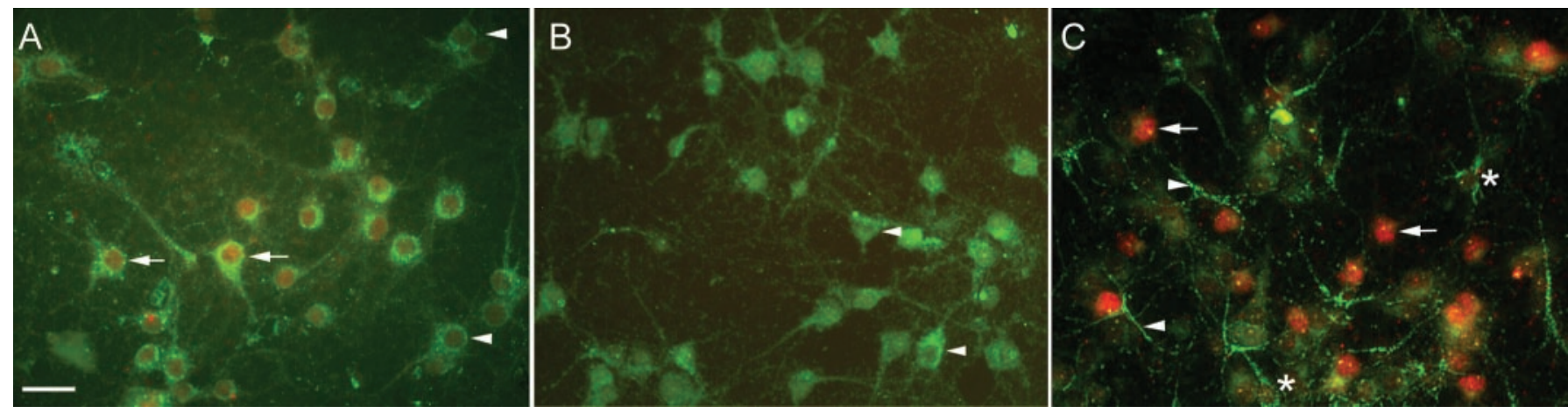

Figure 2. Colocalization of ERs with BDNF and GABA in primary cultures of hippocampal cells. Double-label fluorescent immunocytochemistry was used to colocalize $\mathrm{ER} \alpha$, but not $\mathrm{ER} \beta$, and $\mathrm{BDNF}$ in embryonic hippocampal cell cultures grown in vitro for $5 \mathrm{~d}$. Each panel is an overlay of ER $\alpha$ or $\beta$ and BDNF or GABA immunofluorescence. ER immunoreactivity is visualized as red fluorescence, whereas BDNF or GABA immunoreactivity is green. $A$, Most immunopositive cells were $\mathrm{ER}^{+} / \mathrm{BDNF}^{+}$(arrows), although some $\mathrm{BDNF}^{+}$cells were observed that expressed little or no $\mathrm{ER} \alpha$ immunoreactivity (arrowheads). B, Essentially no ER $\beta$ immunoreactivity was coexpressed with BDNF, and the nuclei of these cells are unstained (arrowheads). $C$, No cells were observed that express $\mathrm{ER} \alpha$ and GABA, although ER $\alpha$-positive cells (arrows) and GABAergic processes (arrowheads) are clearly visible. Although most of the GABA immunoreactivity was concentrated to neuronal processes (arrowheads), we did observe scattered GABA-positive cell bodies that were always $\mathrm{ER} \alpha$-negative (asterisks). Scale bar, $25 \mu \mathrm{m}$.

(MacLusky et al., 1979), we used this experimental protocol to mimic the increase in brain estrogen levels observed early in postnatal life. This allowed us to examine the direct organizational effects of estrogen on BDNF rather than indirect effects resulting from the aromatization of testosterone. Our results demonstrate that the level of BDNF mRNA expression increases in the intact animal from $\mathrm{P} 4$ to $\mathrm{P} 7$ in the $\mathrm{CA} 1$ region and from $\mathrm{P} 4$ to $\mathrm{P} 10$ in the $\mathrm{CA} 3$ region $(p<0.001)$ and then is maintained through adulthood. However, when males are castrated at birth, developing levels are significantly attenuated in these hippocampal subregions. Beginning on P4 and continuing through P10, the levels of BDNF mRNA are significantly less in the hippocampus of castrated males compared with intact controls (CA1, $p=0.002$; CA3, $p=0.003)$. By P15, the levels of BDNF mRNA from castrated animals are no longer significantly different from those of intact males in either the CA1 or CA3 subregion, and this remains the case into adulthood. When neonatally castrated males are given a single injection of estradiol benzoate, the levels of BDNF mRNA expression are significantly higher in the CA1 and CA3 hippocampal subregions from castrated males given vehicle alone $(p<0.001)$. Moreover, the levels of BDNF mRNA expression are not different from intact animals (CA1, $p=0.609$; $\mathrm{CA} 3, p=0.536)$. Even so, in each of these treatment groups, a developmental trend similar to that of intact animals was observed in which BDNF mRNA levels increased during the first 2 postnatal weeks, at which point they were not different from those of adults. Also important to note is that the time course for the effects of estrogen on BDNF mRNA expression are very similar to the transient increase in estrogen receptors in the hippocampus that we have reported previously. These data demonstrate that estrogen significantly increases BDNF mRNA levels in the hip- 
A

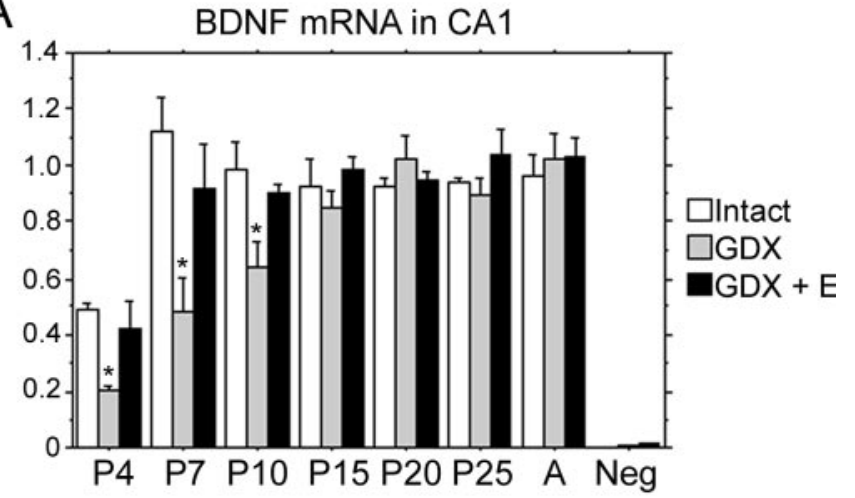

B

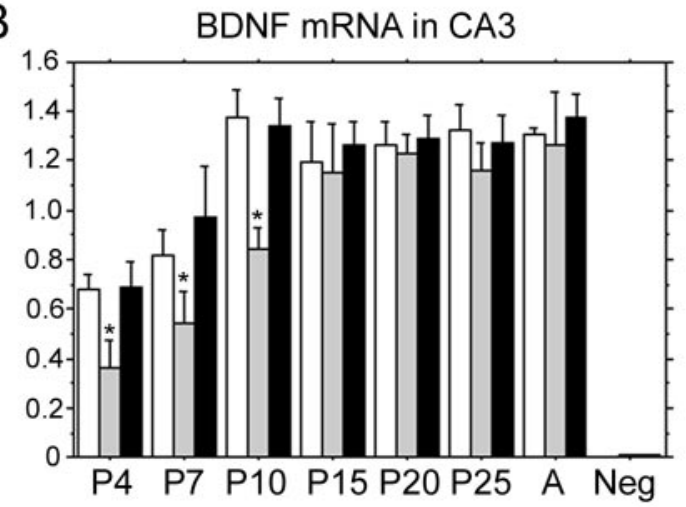

Figure 3. BDNF mRNA levels in the CA1 and CA3 hippocampal subregions of the developing male rat after castration and estrogen replacement. Quantitative real-time RT-PCR was used to examine the expression of BDNF mRNA in the CA1 and CA3 hippocampal subregions of the male rat during development. Animals were gonadectomized $(G D X)$ on $\mathrm{P} 0$ and given a single injection of estradiol $(E)$. All values are reported in picograms of cDNA. Each bar represents the mean of three independent experiments \pm SEM. *Significantly less than other groups at that age $(p<0.005)$. A, Adult; Neg, negative control.

pocampus during development, and this effect is likely mediated through estrogen receptor $\alpha$.

\section{Estrogen effects BDNF mRNA expression in vitro in a dose-dependent manner}

To determine at what concentration estrogen effects on BDNF mRNA expression are observed, we treated primary hippocampal cells with various doses of estrogen ranging from 0.01 to $100 \mathrm{nM}$ (Fig. 4). After estrogen treatment, we examined BDNF mRNA expression with quantitative real-time PCR. Our results demonstrate that estrogen regulates BDNF mRNA expression in a dose-dependent manner. Very low doses $(0.01 \mathrm{~nm})$ of estrogen had no effect, whereas increasing doses resulted in an upregulation of mRNA levels. Treatment with $10 \mathrm{~nm}$ estrogen resulted in a significant increase in BDNF mRNA over control levels, and this was only slightly elevated with higher concentrations. These results confirmed our findings in vivo and demonstrate that estrogen significantly upregulates BDNF mRNA levels in hippocampal cultures. Additionally, these experiments provide evidence to support the use of primary hippocampal cultures as a model for studying effects of estrogen on BDNF expression.

BDNF mRNA levels in the hypothalamus are unaffected by gonadectomy or estrogen replacement

Previous studies have shown that the effect of estrogen on BDNF mRNA expression in the adult varies depending on the brain

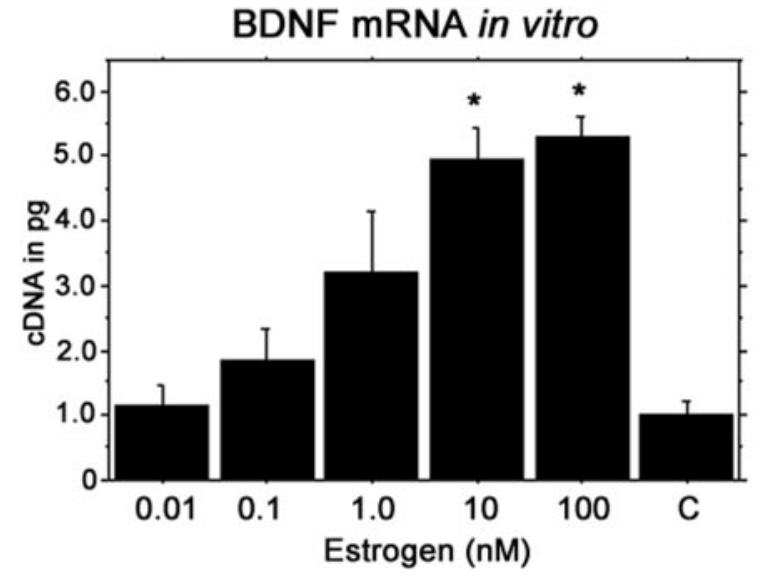

Figure 4. Effects of estrogen on BDNF mRNA expression in primary hippocampal cultures. Primary hippocampal cultures were treated with increasing doses of estradiol benzoate for $24 \mathrm{hr}$, after which BDNF mRNA levels were examined with real-time PCR. All values are reported in picograms of cDNA. Each bar represents the mean of four independent measurements \pm SEM. *Significantly greater than other controls $(p<$ 0.002). C, Control.

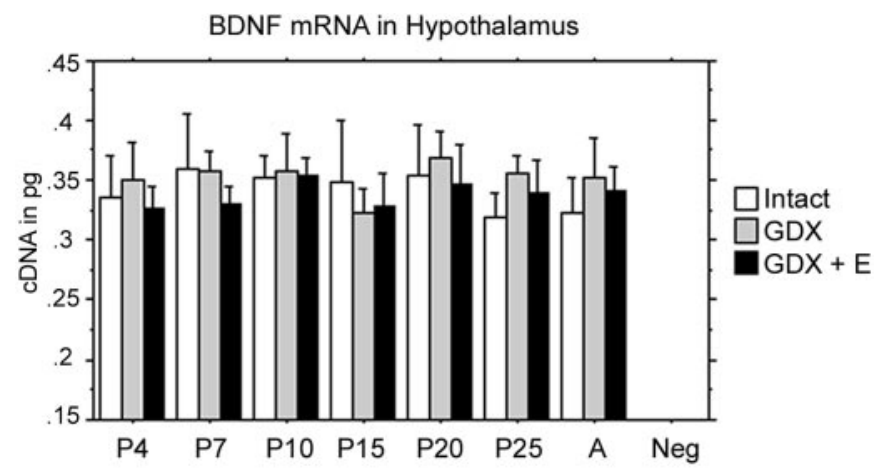

Figure 5. BDNF mRNA levels in the medial basal hypothalamus of the developing male rat after castration and estrogen replacement. Real-time RT-PCR was used to quantitate the expression of BDNF mRNA in the medial basal hypothalamus of the male rat during development. Animals were gonadectomized $(G D X)$ on $\mathrm{P} 0$ and given a single injection of oil vehicle or estradiol benzoate $(E)$. All values are reported in picograms of cDNA. Each bar represents the mean of three independent experiments \pm SEM. No significant differences were observed across development or between treatment groups $(p>0.99)$. A, Adult; Neg, negative control.

region examined (Jezierski and Sohrabji, 2000). To determine whether estrogen affects BDNF mRNA levels in a brain regionspecific manner during development, we examined the medial basal hypothalamus in addition to the hippocampus. The existence and distribution of BDNF mRNA within the adult rat hypothalamus has been well established (Marmigere et al., 1998). Using quantitative real-time PCR, we examined the expression of BDNF mRNA in the developing hypothalamus of intact male rats and neonatal male rats castrated at birth and given a single dose of either $10 \mu \mathrm{g}$ estradiol benzoate or vehicle. Our results demonstrate that BDNF mRNA levels in the hypothalamus of developing male rats were unaffected either by neonatal castration or castration plus estrogen replacement (Fig. 5). Interestingly, we did not observe a significant change across development, and the level of BDNF mRNA expression was generally lower in the hypothalamus when compared with the hippocampus. These findings are similar to those observed in the avian hypothalamus, 
A

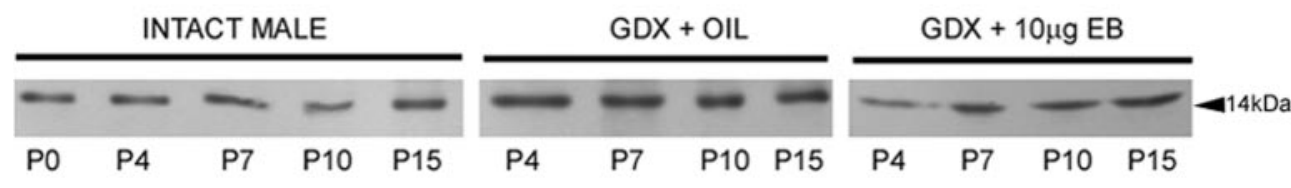

B

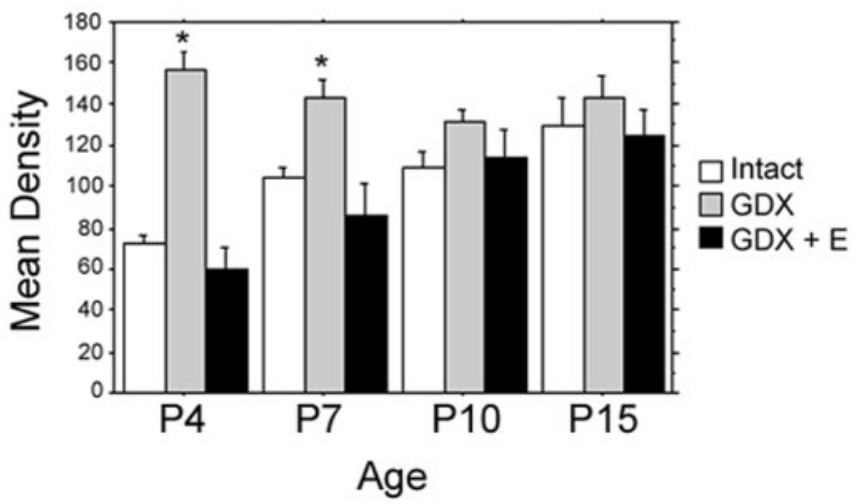

Figure 6. Estrogen regulation of BDNF levels in the developing hippocampus. BDNF levels were measured using Western blot analysis. $A$, A single band of $\sim 14 \mathrm{kDa}$ was detected in hippocampal protein samples from intact, gonadectomized $(G D X)$, and estrogen-treated males during various stages of postnatal development. Males were gonadectomized on postnatal day 0 and immediately treated with a single injection of oil vehicle or estradiol benzoate $(E B)$. $B$, After Western blot analysis of BDNF and actin in the developing hippocampus of intact and hormonemanipulated males, mean optical densities of immunoreactive bands were determined. Background levels were subtracted from these measurements, and a ratio of BDNF/actin was determined to give a mean net density for each age. Each bar represents the mean \pm SEM of three independent experiments. *Significantly greater than other treatment groups at that age ( $p<$ 0.001). E, Estradiol benzoate. where neither acute nor chronic treatment of $17 \beta$-estradiol had an effect on BDNF mRNA levels (Viant et al., 2000).

\section{Neonatal gonadectomy increases BDNF protein levels in the developing hippocampus, and this effect can be reversed by a single injection of estrogen}

After observing an effect of estrogen on BDNF mRNA expression in the developing hippocampus, we next examined whether estrogen had an effect on BDNF protein levels in this brain region as well. We used Western blot analysis to compare the effect of estrogen on BDNF expression in the developing hippocampus of normal males, males castrated at birth, and castrated animals given an injection of estradiol benzoate at the time of castration. These data are presented in Figure 6. In the intact animal, we observed a developmental trend in BDNF protein levels similar to that of BDNF mRNA, in which levels increased from $\mathrm{P} 0$ to $\mathrm{P} 10$ ( $p<0.003)$. However, contrary to our expectations, neonatal castration did not decrease BDNF protein levels as it had with mRNA levels. The results were quite the opposite; from postnatal days 4 to 7 , BDNF levels in the hippocampus were significantly increased after castration at birth $(p<0.001)$. Moreover, when castrated animals were given a single injection of 10 $\mu \mathrm{g}$ of estradiol benzoate, BDNF protein levels were no longer significantly different from those of intact males. To ensure that the immunoreactive bands that we observed were specific for BDNF, we conducted two control experiments including elimination of the primary antibody and preadsorption of the antiserum with the immunoreactive peptide $(100 \mathrm{ng} / \mathrm{ml}, \mathrm{sc}-546 \mathrm{P}$; Santa Cruz Biotechnology). Both of these control experiments completely eliminated the immunoreactive band (data not shown).

\section{Estrogen does not effect trkB mRNA or protein expression in the developing hippocampus}

To determine whether estrogen alters neuronal sensitivity to BDNF by influencing BDNF receptor concentration, we examined the mRNA and protein expression for trkB, the high-affinity BDNF receptor. Using quantitative PCR and Western blot analysis, we did not observe any differences in mRNA (Fig. 7) or protein (Fig. 8) expression in the hippocampus across development when comparing normal males with castrated males treated
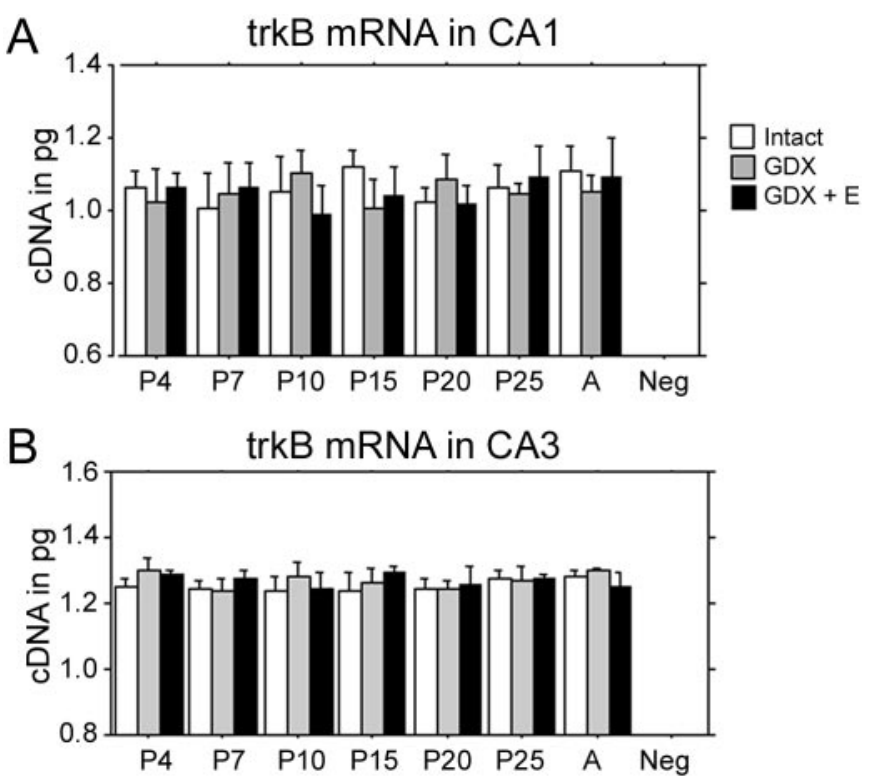

Figure 7. trkB mRNA levels in the CA1 and CA3 hippocampal subregions of the developing male rat after castration and estrogen replacement. Quantitative real-time PCR was used to examine the expression of trkB messenger RNA in the CA1 and CA3 hippocampal subregions of the male rat during development. Animals were gonadectomized $(G D X)$ on postnatal day 0 and given a single injection of oil vehicle or estradiol benzoate $(E)$. All values are reported in picograms of cDNA. Each bar represents the mean \pm SEM of three independent experiments. No significant changes occurred after castration or estrogen replacement at any age examined $(p>0.810)$.

with estradiol benzoate or vehicle. We analyzed trkB mRNA in both the CA1 and CA3 hippocampal subregions from postnatal days 4 to 25 and a group of adult males. Similar to earlier reports using a different technique (Fryer et al., 1996), we detected very little change in expression during the first 2 postnatal weeks, when the levels of mRNA for full-length trkB are no different from adult levels (Fig. 7). Additionally, we did not observe a significant difference between any treatment group at each time point $(p=0.680)$. 
Figure 8. trkB protein levels in the hippocampus of the developing male rat after castration and estrogen replacement. trkB levels were measured using Western blot analysis. $A$, An immunoreactive doublet of $\sim 145 \mathrm{kDa}$ was detected by Western blotting of hippocampal protein samples from intact, gonadectomized $(G D X)$, and estrogen-treated males during various stages of postnatal development. Males were gonadectomized on postnatal day 0 and immediately treated with a single injection of oil vehicle or estradiol benzoate $(E B)$. $B$, After Western blot analysis of trkB and actin in the developing hippocampus of intact and hormone-manipulated males, mean optical densities were determined of immunoreactive bands. Background levels were subtracted from these measurements, and a ratio of trkB/actin was determined to give a mean net density for each age. Each bar represents the mean \pm SEM of three independent experiments. The levels of trkB expression after gonadectomy were not significantly greater than the intact or $G D X+E$ treatment groups $(p>0.68)$.

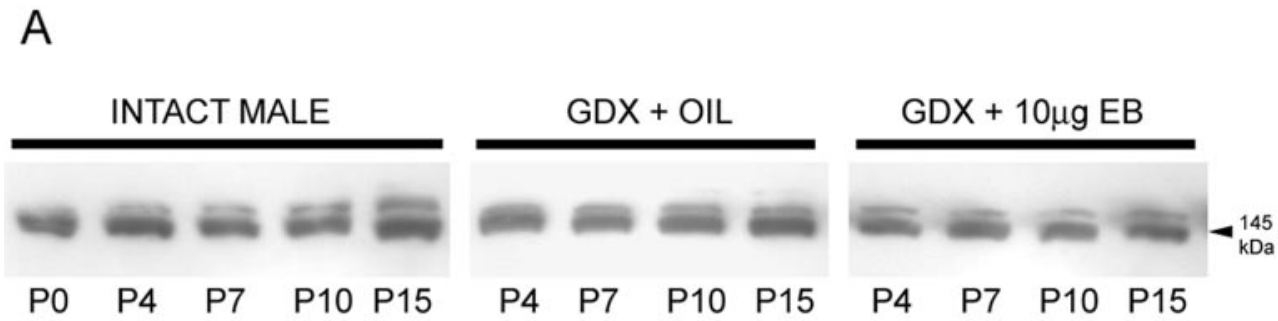

B

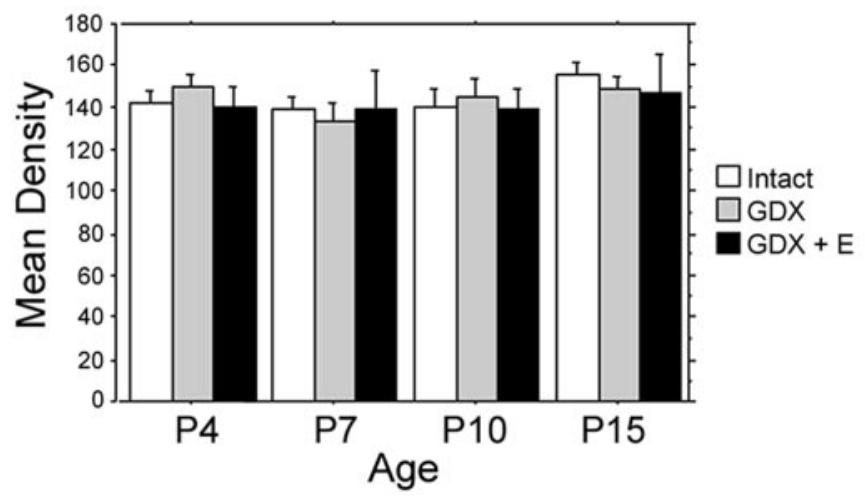

Next, we examined trkB protein expression from postnatal days 4 to 15 in similar treatment groups (Fig. 8). After immunoblotting with anti-trkB serum, we observed an immunoreactive doublet at $\sim 145 \mathrm{kDa}$. The larger band of this doublet represents the predominant full-length receptor, whereas the smaller band likely represents phosphorylated trkB receptors that have been described previously (Kang et al., 1997). Similar to our findings with trkB mRNA, our data demonstrated that estrogen does not regulate the level of trkB protein expression in the developing rat hippocampus. We did not observe any significant differences between intact males and castrated males given estrogen or vehicle. Also, consistent with our finding concerning trkB mRNA, we did not observe any developmental changes in trkB protein levels. These results suggest that estrogen is not acting by modulating trkB but rather on BDNF directly.

\section{DISCUSSION}

In this study, we examined the effect of early steroid environment on BDNF gene expression and demonstrated that neonatal gonadectomy and subsequent estrogen replacement regulates BDNF mRNA and protein expression in the developing rat hippocampus. A quantitative analysis of BDNF mRNA levels in the hippocampus after neonatal gonadectomy and subsequent estrogen replacement revealed a significant increase in BDNF mRNA from postnatal days 4 to 10. Surprisingly, estrogeninduced increases in BDNF mRNA were accompanied by a decrease in BDNF protein levels. However, there was no effect on trkB mRNA or protein expression. Thus, during development, estrogen could influence neuronal differentiation through regulation of BDNF.

Estrogen and numerous growth factors, including the neurotrophins, are associated with neuronal differentiation and survival. Estrogen is important during brain development, influencing the maturation of neural systems and affecting the sexual differentiation of brain structures and functions. Estrogen affects both hypothalamic and hippocampal neuronal physiology and plasticity and promotes growth of the developing nervous system
(Arnold and Gorski, 1984; Toran-Allerand, 1984). Unfortunately, the mechanisms by which estrogen affects the developing hippocampus are ill-defined.

The neurotrophins play important roles in neuronal survival and differentiation (for review, see Thoenen, 1995) and promote neuronal survival during development and after various brain insults (Lindvall et al., 1994; Tucker et al., 2001). Studies have shown that neuronal cultures established during the early stages of neurogenesis are supported by BDNF, whereas older neurons survive with NGF treatment (Enokido et al., 1999). Additionally, BDNF has been shown to induce the formation of both excitatory and inhibitory synapses of embryonic hippocampal cells (VicarioAbejon et al., 1998), providing evidence that BDNF is essential during development.

BDNF has been postulated to be an important signaling molecule in regulating synaptic strength and overall circuit activity in the adult. Accordingly, chronic treatment with BDNF potentiates neurotransmission in the hippocampus (Bolton et al., 2000). $\mathrm{BDNF}$ and its receptor trkB regulate both short-term synaptic functions and long-term potentiation (LTP; McAllister et al., 1999). Estrogen has similarly been shown to enhance LTP (Warren et al., 1995; Foy et al., 1999; Good et al., 1999) and may regulate neural processes underlying learning and memory. The mechanisms by which estrogen modulates LTP are essentially unknown, but one possibility could be through interactions with the BDNF gene.

The colocalization of estrogen receptors with the neurotrophin receptors $\mathrm{p} 75^{\mathrm{NGF}}$, trk $\mathrm{A}$, and $\operatorname{trk\mathrm {B}}$ in the adult basal forebrain established an interaction between estrogen and the neurotrophins (Toran-Allerand et al., 1992; Miranda et al., 1993). Subsequent work demonstrated the presence of an estrogen response element in the BDNF gene (Sohrabji et al., 1995), providing a direct link between estrogen and BDNF. Moreover, estrogen regulates BDNF gene expression in a developmental stage- and brain region-specific manner (Jezierski and Sohrabji, 2000), and this may play important roles in region- and stage-specific regu- 
lation of brain development. Similar to our findings in neonates, it has recently been demonstrated that estrogen significantly affects BDNF mRNA and protein levels in a bidirectional manner within the adult rat hippocampus (Gibbs, 1999). Furthermore, other published reports have shown that estrogen (Liu et al., 2001) and phytoestrogens (Pan et al., 1999) significantly upregulate BDNF mRNA levels in adult mammals.

In addition to its effects on BDNF, estrogen has been shown to influence the expression of neurotrophin receptors. For instance, estrogen upregulates mRNA for the NGF receptor trkA (Sohrabji et al., 1994a,b) and increases trkB in the olfactory bulb (Jezierski and Sohrabji, 2000). However, consistent with the study of Gibbs (1998) in the adult hippocampus, we did not observe an effect of estrogen on trkB mRNA or protein during development. It is possible that estrogen regulates the trk receptors differently depending on the brain region or developmental period examined. Additional studies are needed to examine these differences.

Neurotrophic factors are assumed to provide trophic support via a target-derived, retrograde mechanism. Recent studies have demonstrated that BDNF can also act anterogradely similar to neurotransmitters (Smith et al., 1997; Altar and DiStefano, 1998). It is possible that BDNF produced in hippocampal neurons is transported to downstream targets, such as the basal forebrain and entorhinal cortex, and this transport could be influenced by estrogen, as has been suggested for other brain regions (Jezierski and Sohrabji, 2000). This could account for the increased BDNF mRNA and decreased protein levels after estrogen treatment. This conclusion is supported by a recent report demonstrating an estrogen-induced increase in BDNF levels in hippocampal targets (Liu et al., 2001). Alternatively, differential changes in turnover rates for BDNF mRNA and protein or increases in BDNF levels after neonatal gonadectomy attributable to retrograde uptake and storage from nonhippocampal sites could explain the differences. Estrogen may also act to regulate BDNF expression in different brain regions or periods of development. For instance, Jezierski and Sohrabji (2000) recently demonstrated that estrogen increased BDNF levels in the olfactory bulb and diagonal band of Broca but decreased them in the cingulate cortex. It appears that the effects of estrogen on BDNF are complex and likely dependent on the brain region or age examined.

Similar to our results in vivo, Murphy et al. (1998) showed that estrogen acts to downregulate BDNF levels in hippocampal neurons grown in vitro. These authors suggested that estrogen acts through GABAergic interneurons to regulate BDNF expression. This was based on the findings of Weiland et al. (1997) showing $\mathrm{ER} \alpha$ in interneurons of the adult rat. However, we have recently shown that during development, the highest concentration of $\mathrm{ER} \alpha$ is in CA1 and CA3 pyramidal neurons, and double-labeling experiments demonstrated that these cells did not express GABA (Solum and Handa, 2001; this study). On the basis of our current findings showing that $\mathrm{ER} \alpha$ is colocalized with BDNF in hippocampal pyramidal neurons and studies showing that BDNF is not expressed in interneurons (Pascual et al., 1999), we conclude that there is a direct action of ER on the BDNF gene in pyramidal cells. Even so, it is possible that estrogen regulates the expression of BDNF indirectly through a step involving other transcription-regulating factors. For instance, Murphy et al. (1998) have suggested that BDNF levels could be regulated by cAMP response element-binding protein (CREB) phosphorylation. Even so, this is consistent with our findings, because estrogen has been shown to enhance CREB expression in the hippocampus (Panickar et al., 1997).
The discovery of ER $\beta$ (Kuiper et al., 1996) raised the possibility that some of the effects of estrogen could be mediated by this receptor. Although it has been shown that ER $\beta$ mRNA exists in the adult hippocampus (Shughrue et al., 1997; Shughrue and Merchenthaler, 2001a), ER $\beta$ mRNA does not appear to be translated at significant levels (Shughrue and Merchenthaler, 2001b). Although $\operatorname{ER} \beta$ has been described in the developing mouse hippocampus (Ivanova and Beyer, 2000), it has not been demonstrated whether $\mathrm{ER} \beta$ protein exists during development. Here we have shown that $\mathrm{ER} \beta$ is indeed found at low levels in the developing hippocampus, but it is not colocalized with BDNF, suggesting that the predominant interaction is through $\operatorname{ER} \alpha$. Studies examining splice variants of ER $\beta$ mRNA have suggested that the predominant form in the hippocampus is a variant that does not bind estrogen (Price et al., 2000). Because the two estrogen receptor types can activate different signaling pathways (Webb et al., 1999), it is possible these receptor types may differentially influence the extent and direction of BDNF expression. Although the mechanism underlying estrogen effects on BDNF gene expression remains unclear, differences in $\operatorname{ER} \alpha$ and $\operatorname{ER} \beta$ signaling mechanisms (Jones et al., 1999) and regional expression patterns (Shughrue et al., 1997) may help explain these differences.

Our studies used real-time PCR to analyze the expression of BDNF and trkB mRNA after neonatal gonadectomy. Using a traditional thermal cycler, which relies on end point quantitation, there is theoretically a quantitative relationship between the amount of starting target sequence and amount of product after amplification. Unfortunately, quantitation relies on carefully titrating the product to the linear part of the amplification curve, which is, in reality, a very narrow range. Furthermore, replicate reactions often yield different amounts of PCR product unless elaborate, time-consuming controls are used. Real-time PCR has reduced the variability and expanded the linear range for quantitation by monitoring the product amount after each cycle (Wittwer et al., 1997). Therefore, the optimum cycle number does not need to be determined empirically. This technique has been proven to be a sensitive and quantitative way to assess gene expression in normal development and during pathophysiological conditions (Li and Wang, 2000; Wang et al., 2000) as well as to quantify steroid hormone receptor mRNA levels (Latil et al., 2000).

In summary, previous work in this laboratory has shown that in the neonatal hippocampus, ER $\alpha$ is highly expressed during development. In this study, we have demonstrated that estrogen regulates the expression of BDNF mRNA and protein in the developing rat hippocampus. It is possible then, that estrogen, by binding the $\mathrm{ER} \alpha$, directly alters BDNF gene expression. These findings may contribute to our understanding of the mechanisms by which steroid hormones influence the differentiation of developing neurons.

\section{REFERENCES}

Altar CA, DiStefano PS (1998) Neurotrophin trafficking by anterograde transport. Trends Neurosci 21:433-437.

Arnold AP, Gorski RA (1984) Gonadal steroid induction of structural sex differences in the central nervous system. Annu Rev Neurosci 7:413-442.

Atanassova N, McKinnell C, Walker M, Turner KJ, Fisher JS, Morley M, Millar MR, Groome NP, Sharpe RM (1999) Permanent effects of neonatal estrogen exposure in rats on reproductive hormone levels, Sertoli cell number, and the efficiency of spermatogenesis in adulthood. Endocrinology 140:5364-5373.

Barde YA (1989) Trophic factors and neuronal survival. Neuron 2:1525-1534

Bolton MM, Pittman AJ, Lo DC (2000) Brain-derived neurotrophic 
factor differentially regulates excitatory and inhibitory synaptic transmission in hippocampal cultures. J Neurosci 20:3221-3232.

Buterbaugh GG, Hudson GM (1991) Estradiol replacement to female rats facilitates dorsal hippocampal but not ventral hippocampal kindled seizure acquisition. Exp Neurol 111:55-64.

Chomczynski P, Sacchi N (1987) Single-step method of RNA isolation by acid guanidinium thiocyanate-phenol-chloroform extraction. Anal Biochem 162:156-159.

Cohen-Cory S, Fraser SE (1995) Effects of brain-derived neurotrophic factor on optic axon branching and remodelling in vivo. Nature 378:192-196.

Davies AM (1994) The role of neurotrophins in the developing nervous system. J Neurobiol 25:1334-1348.

Enokido Y, Wyatt S, Davies AM (1999) Developmental changes in the response of trigeminal neurons to neurotrophins: influence of birthdate and the ganglion environment. Development 126:4365-4373.

Foy MR, Xu J, Xie X, Brinton RD, Thompson RF, Berger TW (1999) 17beta-estradiol enhances NMDA receptor-mediated EPSPs and longterm potentiation. J Neurophysiol 81:925-929.

Fryer RH, Kaplan DR, Feinstein SC, Radeke MJ, Grayson DR, Kromer LF (1996) Developmental and mature expression of full-length and truncated TrkB receptors in the rat forebrain. J Comp Neurol 374:21-40.

Gibbs RB (1998) Levels of trkA and BDNF mRNA, but not NGF mRNA, fluctuate across the estrous cycle and increase in response to acute hormone replacement. Brain Res 787:259-268.

Gibbs RB (1999) Treatment with estrogen and progesterone affects relative levels of brain-derived neurotrophic factor mRNA and protein in different regions of the adult rat brain. Brain Res 844:20-27.

Good M, Day M, Muir JL (1999) Cyclical changes in endogenous levels of oestrogen modulate the induction of LTD and LTP in the hippocampal CA1 region. Eur J Neurosci 11:4476-4480.

Henderson VW, Watt L, Buckwalter JG (1996) Cognitive skills associated with estrogen replacement in women with Alzheimer's disease. Psychoneuroendocrinology 21:421-430.

Ivanova T, Beyer C (2000) Ontogenetic expression and sex differences of aromatase and estrogen receptor-alpha/beta mRNA in the mouse hippocampus. Cell Tissue Res 300:231-237.

Jezierski MK, Sohrabji F (2000) Region- and peptide-specific regulation of the neurotrophins by estrogen. Brain Res Mol Brain Res 85:77-84.

Jones PS, Parrott E, White IN (1999) Activation of transcription by estrogen receptor alpha and beta is cell type- and promoter-dependent. J Biol Chem 274:32008-32014.

Juraska JM, Fitch JM, Washburne DL (1989) The dendritic morphology of pyramidal neurons in the rat hippocampal CA3 area. II. Effects of gender and the environment. Brain Res 479:115-119.

Kang H, Welcher AA, Shelton D, Schuman EM (1997) Neurotrophins and time: different roles for TrkB signaling in hippocampal long-term potentiation. Neuron 19:653-664.

Kerr JE, Allore RJ, Beck SG, Handa RJ (1995) Distribution and hormonal regulation of androgen receptor (AR) and AR messenger ribonucleic acid in the rat hippocampus. Endocrinology 136:3213-3221.

Kuhnemann S, Brown TJ, Hochberg RB, MacLusky NJ (1995) Sexual differentiation of estrogen receptor concentrations in the rat brain: effects of neonatal testosterone exposure. Brain Res 691:229-234.

Kuiper GGJM, Enmark E, Pelto-Huikko M, Nilsson S, Gustafsson JA (1996) Cloning of a novel estrogen receptor expressed in rat prostate and ovary. Proc Natl Acad Sci USA 93:5925-5930.

Latil A, Bieche I, Vidaud D, Lidereau R, Berthon P, Cussenot O, Vidaud M (2000) Evaluation of androgen, estrogen (ER alpha and ER beta), and progesterone receptor expression in human prostate cancer by real-time quantitative reverse transcription-polymerase chain reaction assays. Cancer Res 61:1919-1926.

Leranth C, Roth RH, Elswoth JD, Naftolin F, Horvath TL, Redmond Jr DE (2000) Estrogen is essential for maintaining nigrostriatal dopamine neurons in primates: implications for Parkinson's disease and memory. J Neurosci 20:8604-8609.

Levine ES, Dreyfus CF, Black IB, Plummer MR (1995) Brain-derived neurotrophic factor rapidly enhances synaptic transmission in hippocampal neurons via postsynaptic tyrosine kinase receptors. Proc Natl Acad Sci USA 92:8074-8077.

Li X, Wang X (2000) Application of real-time polymerase chain reaction for the quantitation of interleukin-1beta mRNA upregulation in brain ischemic tolerance. Brain Res Protoc 5:211-217.

Lindvall O, Kokaia Z, Bengzon J, Elmer E, Kokaia M (1994) Neurotrophins and brain insults. Trends Neurosci 17:490-496.

Liu Y, Fowler CD, Young LJ, Yan Q, Insel TR, Wang Z (2001) Expression and estrogen regulation of brain-derived neurotrophic factor gene and protein in the forebrain of female prairie voles. J Comp Neurol 433:499-514.

Lohof AM, Ip NY, Poo MM (1993) Potentiation of developing neuromuscular synapses by the neurotrophins NT-3 and BDNF. Nature $363: 350-353$.

Luine VN (1997) Steroid hormone modulation of hippocampal dependent spatial memory. Stress 2:21-36.
MacLusky NJ, Chaptal C, McEwen BS (1979) The development of estrogen receptor systems in the rat brain and pituitary: postnatal development. Brain Res 178:143-160.

Marmigere F, Rage F, Tapia-Arancibia L, Arancibia S (1998) Expression of mRNAs encoding BDNF and its receptor in adult rat hypothalamus. NeuroReport 9:1159-1163.

McAllister AK, Lo DC, Katz LC (1995) Neurotrophins regulate dendritic growth in developing visual cortex. Neuron 15:791-803.

McAllister AK, Katz LC, Lo DC (1999) Neurotrophins and synaptic plasticity. Annu Rev Neurosci 22:295-318.

McCormick CM, Furey BF, Child M, Sawyer MJ, Donohue SM (1998) Neonatal sex hormones have "organizational" effects on the hypothalamic-pituitary-adrenal axis of male rats. Brain Res Dev Brain Res 105:295-307.

McEwen BS (1983) Gonadal steroid influences on brain development and sexual differentiation. Int Rev Physiol 27:99-145.

Miranda RC, Sohrabji F, Toran-Allerand CD (1993) Presumptive estrogen target neurons express mRNAs for both the neurotrophins and neurotrophin receptors: a basis for potential developmental interactions of estrogen with the neurotrophins. Mol Cell Neurosci 4:510-525.

Miranda RC, Sohrabji F, Toran-Allerand D (1994) Interactions of estrogen with the neurotrophins and their receptors during neural development. Horm Behav 28:367-375.

Morrison TB, Weis JJ, Wittwer CT (1998) Quantification of low-copy transcripts by continuous SYBR Green I monitoring during amplification. Biotechniques 24:954-958, 960-962.

Murphy DD, Cole NB, Segal M (1998) Brain-derived neurotrophic factor mediates estradiol-induced dendritic spine formation in hippocampal neurons. Proc Natl Acad Sci USA 95:11412-11417.

Pan Y, Anthony M, Clarkson TB (1999) Evidence for up-regulation of brain-derived neurotrophic factor mRNA by soy phytoestrogens in the frontal cortex of retired breeder female rats. Neurosci Lett 261:17-20.

Panickar KS, Guan G, King MA, Rajakumar G, Simpkins JW (1997) 17beta-estradiol attenuates CREB decline in the rat hippocampus following seizure. J Neurobiol 33:961-967.

Pascual M, Acsady L, Rocamora N, Freund TF, Soriano E (1999) Expression of neurotrophins in hippocampal interneurons immunoreactive for the neuropeptides somatostatin, neuropeptide-Y, vasoactive intestinal polypeptide and cholecystokinin. Neuroscience 89:1089-1101.

Price Jr RH, Lorenzon N, Handa RJ (2000) Differential expression of estrogen receptor beta splice variants in rat brain: identification and characterization of novel variant missing exon 4. Mol Brain Res 80: $260-268$.

Roof RL, Havens MD (1992) Testosterone improves maze performance and induces development of a male hippocampus in females. Brain Res $572: 310-313$.

Sherwood NT, Lo DC (1999) Long-term enhancement of central synaptic transmission by chronic brain-derived neurotrophic factor treatment. J Neurosci 19:7025-7036.

Shughrue PJ, Merchenthaler I (2001a) Evidence for novel estrogen binding sites in the rat hippocampus. Neuroscience 99:605-612.

Shughrue PJ, Merchenthaler I (2001b) Distribution of estrogen receptor beta immunoreactivity in the rat central nervous system. J Comp Neurol 436:64-81.

Shughrue PJ, Lane MV, Merchenthaler I (1997) Comparative distribution of estrogen receptor-alpha and -beta mRNA in the rat central nervous system. J Comp Neurol 388:507-525.

Singh M, Meyer EM, Simpkins JW (1995) The effect of ovariectomy and estradiol replacement on brain-derived neurotrophic factor messenger ribonucleic acid expression in cortical and hippocampal brain regions of female Sprague-Dawley rats. Endocrinology 136:2320-2324.

Smith MA, Zhang LX, Lyons WE, Mamounas LA (1997) Anterograde transport of endogenous brain-derived neurotrophic factor in hippocampal mossy fibers. NeuroReport 8:1829-1834.

Smith SS (1994) Female sex steroid hormones: from receptors to networks to performance-actions on the sensorimotor system. Prog Neurobiol 44:55-86.

Sohrabji F, Miranda RC, Toran-Allerand CD (1994a) Estrogen differentially regulates estrogen and nerve growth factor receptor mRNAs in adult sensory neurons. J Neurosci 14:459-471.

Sohrabji F, Greene LA, Miranda RC, Toran-Allerand CD (1994b) Reciprocal regulation of estrogen and NGF receptors by their ligands in PC12 cells. J Neurobiol 25:974-988.

Sohrabji F, Miranda RCG, Toran-Allerand D (1995) Identification of a putative estrogen response element in the gene encoding brain-derived neurotrophic factor. Proc Natl Acad Sci USA 92:11110-11114.

Solum D, Handa RJ (2001) Localization of estrogen receptor alpha $(\mathrm{ER} \alpha)$ in pyramidal neurons of the developing rat hippocampus. Brain Res Dev Brain Res 128:165-175.

Terasawa E, Timiras PL (1968) Electrical activity during the estrous cycle of the rat: cyclical changes in limbic structures. Endocrinology 83:207-216.

Thoenen H (1995) Neurotrophins and neuronal plasticity. Science 270:593-598.

Toran-Allerand CD (1984) On the genesis of sexual differentiation of 
the central nervous system: morphogenetic consequences of steroidal exposure and possible role of $\alpha$-fetoprotein. Prog Brain Res 61:63-98.

Toran-Allerand CD, Miranda RC, Bentham WD, Sohrabji F, Brown TJ, Hochberg RB, MacLusky NJ (1992) Estrogen receptors colocalize with low-affinity nerve growth factor receptors in cholinergic neurons of the basal forebrain. Proc Natl Acad Sci USA 89:4668-4672.

Toran-Allerand CD, Singh M, Setalo Jr G (1999) Novel mechanisms of estrogen action in the brain: new players in an old story. Front Neuroendocrinol 20:97-121.

Tucker KL, Meyer M, Barde YA (2001) Neurotrophins are required for nerve growth during development. Nat Neurosci 4:29-37.

Ulibarri C, Popper P, Micevych PE (1990) Role of postnatal androgens in sexual differentiation of the lordosis-inhibiting effect of central injections of cholecystokinin. J Neurobiol 21:796-807.

Viant MR, Millam JR, Delany ME, Fry DM (2000) Regulation of brainderived neurotrophic factor messenger RNA levels in avian hypothalamic slice cultures. Neuroscience 99:373-380.

Vicario-Abejon C, Collin C, McKay RDG, Segal M (1998) Neurotrophins induce formation of functional excitatory and inhibitory synapses between cultured hippocampal neurons. J Neurosci 18:7256-7271.

Wang X, Li X, Currie RW, Willette RN, Barone FC, Feuerstein GZ
(2000) Application of real-time polymerase chain reaction to quantitate induced expression of interleukin-1beta mRNA in ischemic brain tolerance. J Neurosci Res 59:238-246.

Warren SG, Humphreys AG, Juraska JM, Greenough WT (1995) LTP varies across the estrous cycle: enhanced synaptic plasticity in proestrus rats. Brain Res 703:26-30.

Webb P, Nguyen P, Valentine C, Lopez GN, Kwok GR, McInerney E, Katzenellenbogen BS, Enmark E, Gustafsson JA, Nilsson S, Kushner PJ (1999) The estrogen receptor enhances AP-1 activity by two distinct mechanisms with different requirements for receptor transactivation functions. Mol Endocrinol 13:1672-1685.

Weiland NG, Orikasa C, Hayashi S, McEwen BS (1997) Distribution and hormone regulation of estrogen receptor immunoreactive cells in the hippocampus of male and female rats. J Comp Neurol 388:603-612.

Wittwer CT, Ririe KM, Andrew RV, David DA, Gundry RA, Balis UJ (1997) The LightCycler: a microvolume multisample fluorimeter with rapid temperature control. Biotechniques 22:176-181.

Woolley CS, McEwen BS (1992) Estradiol mediates fluctuation in hippocampal synapse density during the estrous cycle in the adult rat. J Neurosci 12:2549-2554. 